Research Article

\title{
Analysis of Neutronic Safety Parameters of the Multi-Purpose Reactor-Gerrit Augustinus Siwabessy (RSG-GAS) Research Reactor at Serpong
}

\author{
Tukiran Surbakti ${ }^{1, a, b}$ and Purwadi ${ }^{2, c}$ \\ ${ }^{1}$ Pusat Teknologi dan Keselamatan Reaktor Nuklir (PTKRN), Badan Tenaga Atom Nasional (BATAN) \\ Kawasan Puspiptek Gd 80 Serpong, Tangerang Selatan, Banten 15310, Indonesia \\ ${ }^{2}$ Pusat Reaktor Serbaguna (PRSG), Badan Tenaga Atom Nasional (BATAN) \\ Kawasan Puspiptek Gd 30 Serpong, Tangerang Selatan, Banten 15310, Indonesia \\ e-mail: ${ }^{a}$ tukiran@batan.go.id , ${ }^{b}$ tsurbakti@yahoo.com, and c purwadi14@batan.go.id
}

\begin{abstract}
The main safety parameters of Multipurpose Reactor-Gerrit Augustinus Siwabessy (RSG-GAS) have never been evaluated periodically and neutronically require to be evaluated in terms of stuck rod reactivity, shut-down margin and temperature reactivity coefficient are treated by experiment. Meanwhile, power peaking factors and maximum fuel burn up are treated by calculations. The diffusion method did the calculation using the computer code. Safety parameters are very important aspects for the operation and design improvement. The results of the experiment and calculation about the safety parameters of RGS-GAS core are utilized for safety evaluation as part of a research reactor operation Periodic Safety Review (PSR). It presents reactor calculations as a method for their determination assuming use of computer codes such as WIMSD-5B using ENDF.BVII.0 and BATAN-FUEL. According to the experimental data and calculation, neutronic safety parameters have met the safety analysis report such as reactivity coefficient is negative and met the shutdown margin at stuck rod condition nothing has violated the safety margin. The results can be used as the periodic safety review for renewal operation license from Nuclear Energy Regulatory Agency of Indonesia (BAPETEN) as the regulator body. These results also can be used as a reference for new research reactor MTR type advanced design in the future.
\end{abstract}

Keywords: research reactor, safety parameter, WIMSD-5B, BATAN-FUEL

\section{Analisis Parameter Keselamatan Neutronik pada Teras Reaktor Serba Guna-Gerrit Augustinus Siwabessy (RSG-GAS) di Serpong}

\begin{abstract}
Abstrak
Parameter utama keselamatan reaktor RSG-GAS secara periodik belum pernah dievaluasi sehingga secara neutronik perlu dievaluasi seperti reaktivitas stuck rod, shut-down margin dan koefisien reaktivitas suhu yang dapat ditentukan secara eksperimen. Sementara itu, faktor puncak daya dan fraksi bahan bakar maksimum ditentukan dengan perhitungan. Perhitungan dilakukan dengan metode difusi. Parameter keselamatan merupakan hal yang sangat penting untuk operasi dan peningkatan desain di masa depan. Hasil eksperimen dan perhitungan tentang parameter keselamatan teras reactor RSG-GAS digunakan untuk evaluasi keselamatan yang dilakukan sebagai bagian dari evaluasi keselamatan
\end{abstract}

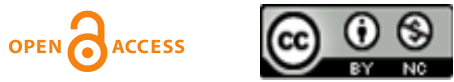


Jurnal Penelitian Fisika dan Aplikasinya (JPFA), 2019; 9(1): 78-91

operasi reaktor riset secara periodik. Perhitungan teras reaktor disajikan sebagai metode untuk penentuan parameter keselamatan neutronik dilakukan dengan menggunakan program komputer yang tersedia di Batan seperti WIMSD-5B menggunakan data nuklir ENDF.BVII.O dan Batan-FUEL. Menurut hasil perhitungan dan eksperimen, parameter keselamatan neutronik memenuhi batas keselamatan yang ada di laporan analisis keselamatan dan tidak ada yang melanggar batas keselamatan seperti koefisien reaktivitas yang dihasilkan adalah negatif dan kondisi stuck rod terpenuhi. Hasil ini dapat digunakan sebagai tinjauan Penilaian Keselamatan Berkala (PKB) untuk lisensi operasi RSG-GAS yang baru dari BAPETEN sebagai badan pengawas operasi reaktor nuklir. Hasil evaluasi ini juga dapat digunakan sebagai referensi untuk mendesain reaktor riset baru berbahan bakar tipe plat dimasa yang akan datang.

Kata Kunci: reaktor riset, parameter keselamatan, WIMSD-5B, BATAN-FUEL

PACS: 28.50.Dr, 28.52.Nh

(C) 2019 Jurnal Penelitian Fisika dan Aplikasinya (JPFA). This work is licensed under CC BY-NC 4.0

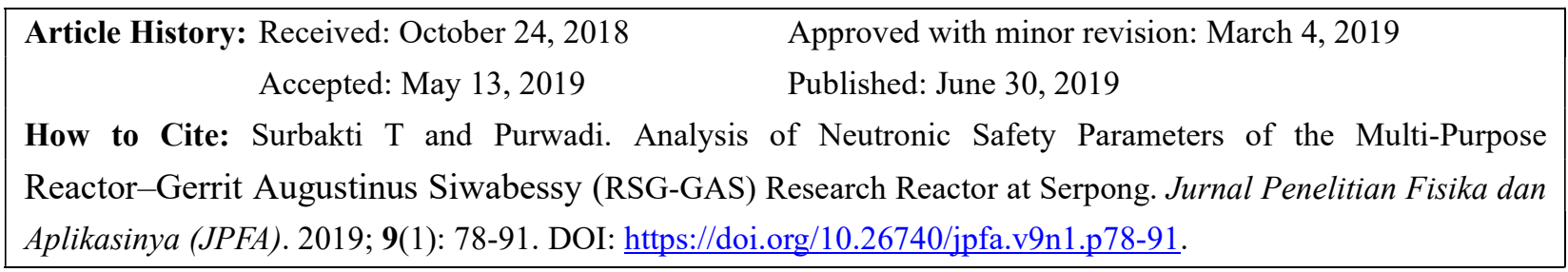

\section{INTRODUCTION}

All activities during normal operation at the Multipurpose Reactor-Gerrit Augustinus Siwabessy (RSG-GAS) research reactor require safety evaluation. In principle, safety evaluation should support any activity that may affect neutronic parameters of the reactor operation [1]. Some main activities that involve evaluating the safety RSG-GAS reactor operation are namely to replace the reactor components, power uprating, fuel element type change, oxide-silicide mixed core operation, new experimental setups, spent fuel storage, and reactor ageing. Reactor safety evaluation related to major modifications in the reactor system must be carried out by changing the reactor safety analysis report document performed by relevant competent institutions. RSG-GAS operational team, however, is likely neither qualified nor equipped for such work in the research reactor. Nevertheless, due to the experimental nature of RSG-GAS research reactor, certain activities requiring safety evaluations should be performed by the operational team themselves, for example modifications of core configuration due to experiments and fuel management.

The importance of safety parameters on the reactor operation is to maintain the safety in the design as well as during the operation of RSG-GAS reactor. Advanced computer codes are widely used as the tools in the frameworks of renewal operation license and Periodic Safety Review (PSR). So far, PSR is yet to be performed at RGS-GAS, despite its requirement to be conducted every 10 years to review which safety parameters which should be evaluated and improved.

The purpose of this study is to explain the most important safety parameters of the RSG-GAS research reactor from reactor operational aspect whilst simultaneously acts as the PSR. Safety parameters discussed in this paper are as follows: power distributions and power peaking factor, shutdown margin, and temperature reactivity coefficients. This review utilizes computer codes and integrated packages adapted to the practical needs in the core management, namely 
WIMSD-5B

and

BATAN-FUEL.

WIMSD-5B [2] code is used to generate $\mathrm{x}$-section of the RSG-GAS core materials. Meanwhile, BATAN-FUEL [3] code is employed in calculating the core parameter. These codes are performed for the neutronic safety parameters and verified using RSG-GAS core data $[4,5,6]$.

\section{METHOD}

The research was carried out by collecting reactor operation data, disturbance data, incidents and reactor operation accidents, data processing and evaluation of RSG-GAS reactor safety parameters. Data collection activities were conducted for design data, operating parameter data including disturbance data, incident and reactor accidents over time from core configuration number 6 to 95 [7-11].

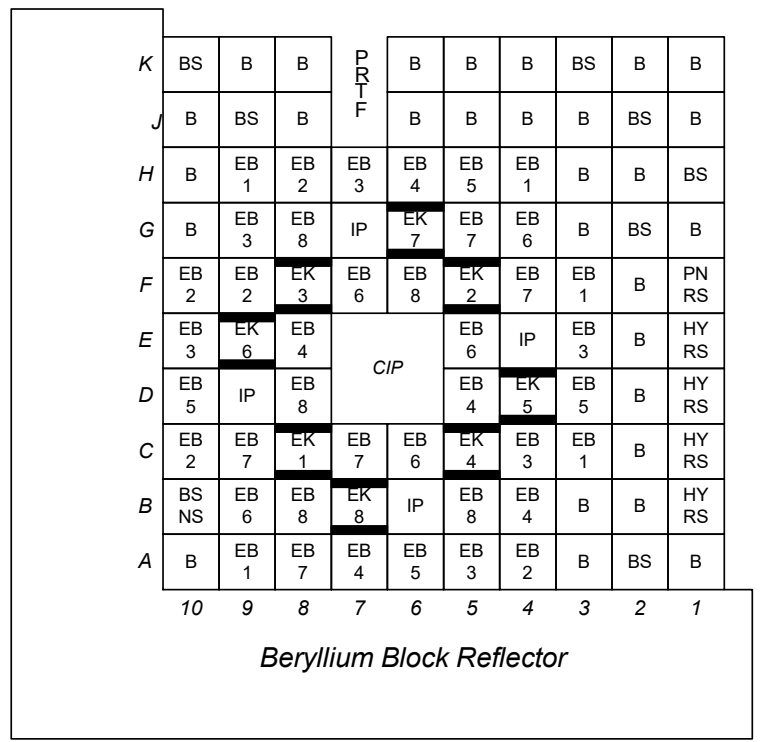

Where: $\mathrm{EB}=$ Standard Fuel Element; EK = Standard Control Element; BE = Beryllium Reflector Element; $\mathrm{BS}=$ Beryllium Reflector Element with plug; IP = Irradiation Position; CIP = Center Position Irradiation; PNRS = Pneumatic Rabbit System; HYRS = Hydraulic Rabbit System.

Figure 1. RSG-GAS Core Configuration (Numbers at EB and EK are Burn-Up Class) [12]

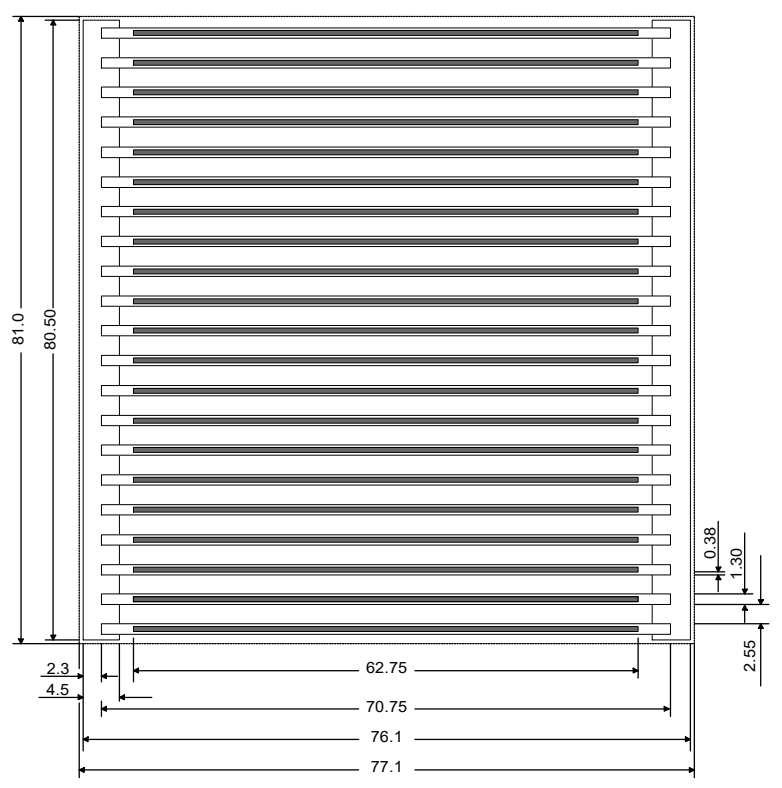

Figure 2. Standard Fuel Elements of the RSG-GAS Reactor [13]

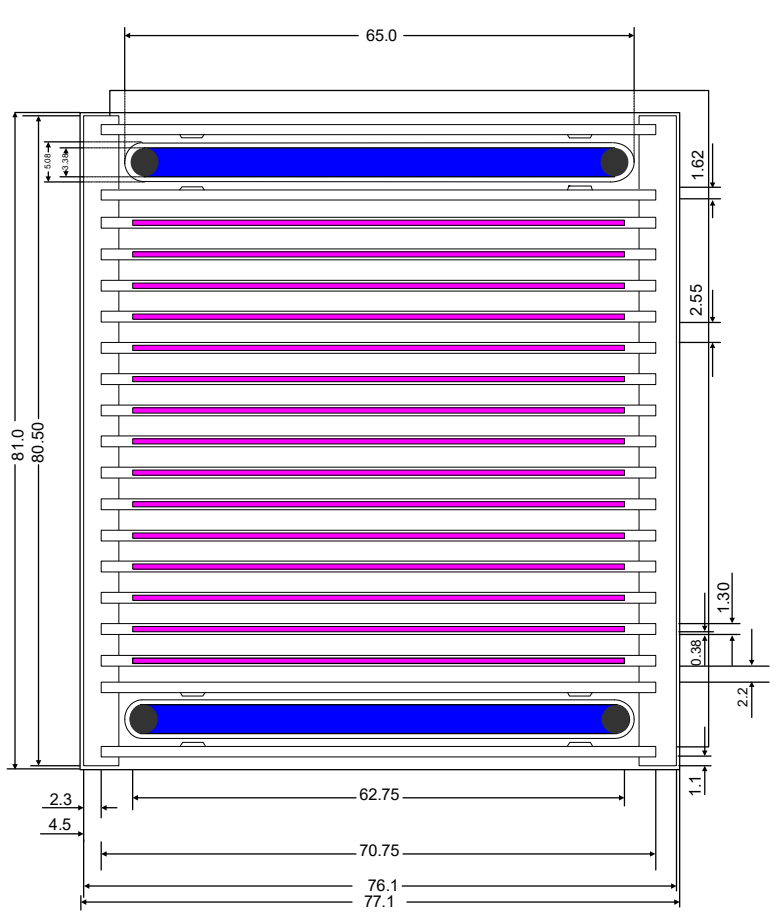

Figure 3. Control Rod Fuel Element of the RSG-GAS Reactor [13]

\section{Experimental Data}

Shutdown Margin (SDM) is the amount of reactivity available, where reactor becomes a subcritical state if all control rods are inserted to the reactor core completely. If a single rod with the highest integral reactivity value, which is assumed to be fully with 
drawn or stuck, the control rods must have a negative reactivity to make the reactor subcritical state. Reactivity shut-down margin of the reactor is very important to determine experimentally; it is usualy around 1-5\% provided for safety purposes. However, stuck rod criterion refers to the fact that reactivity shut-down margin should be available even though one contol rod stuck cannot enter the reactor core. Implementing stuck rod criteria is to unsure the failure of a single control rod and will not prevent the control rod system from shuting down the reacor. It requires a shut-down margin to exist at reactor operating. The reactor can either be critical or safe subcritical when stuck rod condition occured. Sub-criticality with $k_{\text {eff }}=0.99$ with all control rods inserted to the core is not the safe subcritical condition [14].

RSG GAS (MPR-30) research reactor is operating at $15 \mathrm{MWt}$. For each core cycle before the criticality experiment (beginning of the cycle), it was conducted criticality calculations with the purpose (1) for the specific core and to determine the Control Rod (CR) that had the most reactivity worth and (2) for One-Stuck-Rod (OSR) conditions. The OSR condition is simulated by withdrawing a control rod and inserting the rest into the core. As we have $8 \mathrm{CRs}$, then we conducted 8 different criticality calculations. Under any OSR condition, the calculated neutron multiplication factor $\left(k_{\text {eff }}\right)$ must be lower than 0.98 , or at least $1 \%$ shut-down margin for OSR. If it is inserted for all CRs, $\mathrm{k}_{\text {eff }}$ should be much less than 0.98 . It sets the shut-down margin for OSR to be at least $1 \%$ because it would come from regulatory aspects and accuracy of the analytical tools that is used. As the RSG GAS reactor does not employ burnable poison, the OSR at the begining the cycle (BOC) is the severest, so it was checked only OSR as the BOC [15].
During power operation, SDM is ensured by operating with the shut-down banks with drawn and the control banks within the so-called "rod insertion limits" specified in the technical specifications. If the operator wants to shut down the reactor from Hot Full Power - equilibrium xenon to Hot Zero Power - with xenon, for example, in case of reactor SCRAM, they must insert negative reactivity to compensate the power defect. It is obvious, if the power defect for RSG-GAS is about $3000 \mathrm{pcm}$, the control rods must weigh over $3000 \mathrm{pcm}$ to achieve the subcritical condition. It typically requires a shut-down margin ranging from 1 to 5 percent reactivity. Therefore, to ensure the safe subcritical condition, the control rods must weigh over $3000 \mathrm{pcm}$ plus the value of SDM. The total weight of control rods is design specific value, but namely it may reach about 14.200 pcm [16].

\section{Calculation Data}

The calculation data divides the method to achieve the research aim into two types of calculations. This section elaborates on these two calculation types.

\section{Cell Calculation}

To solve the neutron kinetics equations, the macroscopic cross-section library for various materials in the core was set-up. For this purpose, it utilized the WIMSD-5B lattice code. It identified the cells which may correspond to any region of the core (fueled and non-fueled). It considered when defining the unit cell dimensions, the principles of conservation of volume ratio of the different material in the fuel assembly. Fuel assembly in the core configuration is shown in Figure 1.

Fuel cell dimensions were calculated considering the fuel meat conservation criteria. It showed the unit cell for fuel element ( $\mathrm{FE}$ in Figure 2 it added an extra region accounting for the remaining water and 
aluminum in the same proportions as in the physical fuel element, this region includes the aluminum in the plates beyond the width of the meat and the aluminum side plates, the water beyond the width of the meat, and the water channels surrounding the fuel element). In the particular case of the control element, it used the super-cell option of WIMSD-5B. It modeled the representative cell with 15 regions. It shows the control rod and box absorber in Figure 3. WIMSD-5B code generates the macroscopic cross-section data as a function of burn-up and fuel and moderator temperatures. Different burn-up values, ranging from $0 \%$ to $90 \%$ were considered generating all conditions, the beginning of cycle, and the end of cycle cores [17].

Fuel and moderator temperatures cover a large set of core condition for normal and transient conditions. A macroscopic cross-section was generated to determine the average speed of neutrons. It generates the cross-section in 4 neutron energy groups, but when determining the average speed of neutrons, it occurred in the 69 neutron energy groups. It used the average speed of neutrons in 4 groups of power calculated by weighting the speed of neutrons in 69 energy groups with an average cell flux [18]. The speed of a neutron was used to calculate total delayed neutron fraction. Steps of cell calculation are as follows: [19]

a. The macroscopic $\mathrm{x}$-section as a function of burn- up was generated under ambient conditions $\left(20^{\circ} \mathrm{C}\right)$.

b. The macroscopic $\mathrm{x}$-section for fuel elements was generated as a function of temperatures $\left(50^{\circ} \mathrm{C}, 100^{\circ} \mathrm{C}, 150^{\circ} \mathrm{C}\right.$, $\left.200^{\circ} \mathrm{C}\right)$.

c. The macroscopic $\mathrm{x}$-section for a moderator was generated as a function of temperatures $\left(35^{\circ} \mathrm{C}, 45^{\circ} \mathrm{C}, 60^{\circ} \mathrm{C}, 80^{\circ} \mathrm{C}\right.$, $100^{\circ} \mathrm{C}$ ). In this step, no moderator density effect was included.

\section{Core Calculation}

The neutronic design procedure is shown in the schematic diagram of Figure 4. First, the cross section library for fissile and non-fissile materials was prepared with the WIMSD-5B cell calculation code. The library was prepared to accommodate wide ranges of design parameters such as fuel burnup level, fuel meat density, fuel operational temperature, and existence of important neutron poisons (xenon and samarium). The general reactor data, refueling and fuel reshuffling strategy, and the core cycle length were fed into a dedicated in-core fuel management code module, Batan-EQUIL-2D [20].

The main function of Batan-EQUIL-2D code is to directly search for the equilibrium core without simulating the transition cores. Since the code used 2-D diffusion theory, an accurate axial buckling must be provided through rigorous 3-D diffusion calculations by the Batan-3DIFF module. As the equilibrium core with the prescribed core cycle length is obtained, and then a check was done to determine whether the excess reactivity at the End of Cycle (EOC) under the hot and xenon equilibrium condition was sufficient. If the initially specified core cycle length was not appropriate, adjustment should be carried out to provide sufficient EOC excess reactivity [21]. It then conducted the calculations in 2-D diffusion theory with the Batan-2DIFF module to check the one-stuck-rod subcritical condition. If it did not satisfy this safety requirement, modification to the FEs' arrangement should be done across the core or even the refueling and reshuffling strategy. Similar adjustments were needed to get a flat power distribution across the core [22]. 


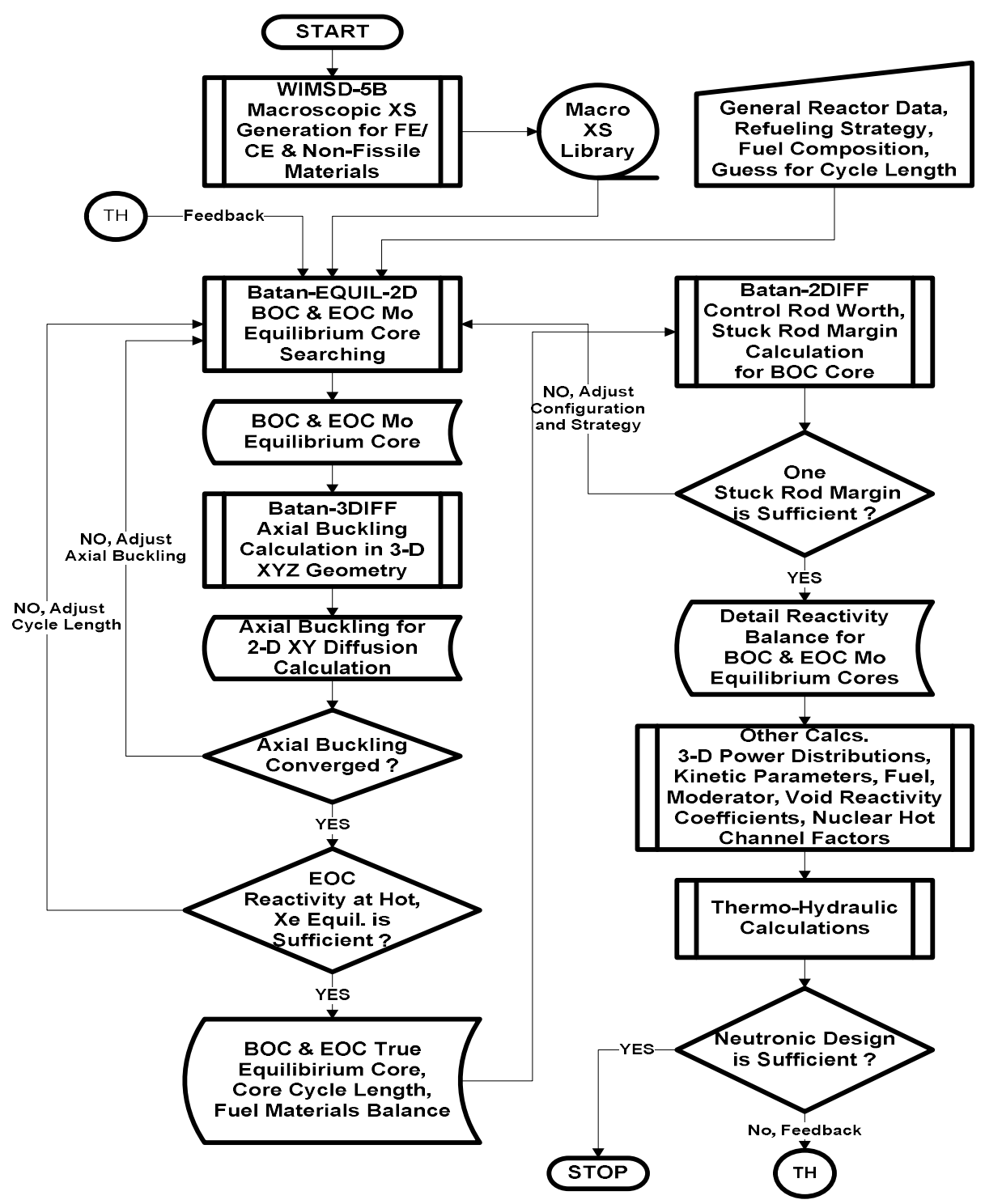

Figure 4. Neutronic Safety Parameter

Calculation for RSG-GAS Core [23]

Some kinetic parameters are not discussed here in the last part of the neutronic design procedure covering the kinetic parameters and, of most importance, the nuclear hot channel factors.

\section{III.RESULTS AND DISCUSSION Maximum Discharged Burn-Up}

The accuracy of burn-up calculations depends on the isotopic burn-up schemes and data used in the depletion code. The capture and fission in ${ }^{235} \mathrm{U}$ and absorption in ${ }^{238} \mathrm{U}$ and fission products are predominant reactions. Production of $\mathrm{Pu}$ isotopes by resonance absorption in ${ }^{238} \mathrm{U}$ and their fission in research reactors are not important due to high enrichment and uranium concentration. Spectrum deformations and shifts due to bum-up do not influence the isotopic composition changes like in low enriched power reactors. The excess reactivity changes with burn-up are in research reactors sensitive to the uranium, main fission product, and case burnable poison nuclear data. Comparison of calculated bum-up reactivity reduction slopes to the experimental ones often shows a much bigger discrepancy than expected from the quality of nuclear data affecting the burn-up 
and other inaccuracies of the calculation models. One of the most frequent reasons is the systematic error in power calibration because the burn-up is proportional to reactor power. In RSG-GAS research reactor, it calibrated the power regarding a single neutron detector. Its response is proportional to the flux at its position. Local flux is proportional to the total flux (power) of the reactor only if its radial and axial distributions do not change. This is, however, not the case in the reactor where operational reactivity changes (burn-up, power defect, xenon effect) are compensated by moving the control rods.

The results of the experimental and calculation for burn-up fuel of the RSG-GAS core had been validated at core 87 . The maximum discharged burn-up for RSG-GAS core with silicide fuel is limited to $59.99 \%$. This limit is the operating limit so it cannot be exceeded. From the results of the calculation in Figure 5 using BATAN-FUEL code, the fuel of RSG-GAS working core is never exceeded the maximum discharged burn-up except at cores of 40,41 , and 42 which are $61.04,64.95,67.39$ respectively due to fuel placement errors. But this fuel has not exceeded the safety margin of $70 \%$. It already gives the results to the Bapaten in order to review the periodic safety.

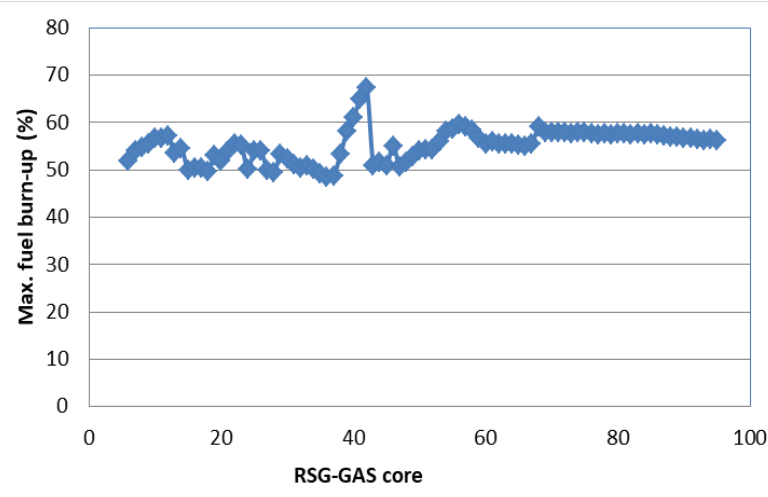

Figure 5. Maximum Discharged Burn-Up for RSG-GAS Core

\section{Power Distributions}

Fuel temperature is one of the most important limiting conditions on RSG-GAS reactor operation. It depends on the reactor design, thermal-hydraulics properties and the power density released in fuel. Power density distribution depends on the core configuration and loading pattern. The fuel temperature is affected by the burn-up even if it does not change the loading pattern. It is the responsibility of the reactor operator to keep the fuel temperature and the maximum power density within the limits prescribed by the safety analysis report. Limitations are imposed on maximum fuel temperature. Limiting temperatures and other thermal-hydraulic parameters are defined by the design properties of reactor fuel and other components (mechanical design, cladding stress, corrosion); it limits the maximum temperature in RSG-GAS fuel plate to $200^{\circ} \mathrm{C}$. As the temperature is in steady-state conditions proportional to the power, the temperature limitations also define the power density limitations. Power density limitations resulted from the thermal-hydraulics analysis is beyond the authority or area of the reactor operation team. It derives limitations from the assumptions on the thermal power density distribution and its integral equal to total reactor power. The assumptions on power density distribution are conservative covering a wide range of modes and conditions in reactor operation. In principles, it includes the assumptions on power distributions in the safety analysis report as they make the input to the thermal-hydraulics analysis. It is the responsibility of the reactor operator to accommodate the operating conditions, loading pattern and the experiments such that it does not violate the power limitations. However, this requirement is very difficult to respect due to practical reasons, namely the experimental information on the power distributions in the fuel is limited. The only 
online information is fuel temperature. Power distributions are measured only by measuring flux distribution. However, in the RSG-GAS reactor as a plate-type fuel, such measurements only yield indirect information on flux and power inside fuel elements which is the actual limitation. Reactor calculations are the most practical and workable method for power density distribution analysis; it can see power peaking factor of RSG-GAS Core 95 in the Figure 6 which is maximum at C-8 position 1.23 , near the control rod and the gap or empty position. The safety limit of the maximum value of the PPF is 1.4 (SAR).

\begin{tabular}{|c|c|c|c|c|c|c|c|}
\hline \multirow[t]{2}{*}{ B-26 } & Rl-609 & RI-602 & RI-587 & RI-589 & Rl-586 & RI-605 & \multirow[t]{2}{*}{ B-19 } \\
\hline & 1.0161 & 0.9603 & 0.9176 & 0.9305 & 0.8372 & 0.9880 & \\
\hline \multirow[t]{2}{*}{ B-16 } & RI-599 & RI-570 & AL-4 & RI-583 & Rl-575 & RI-576 & \multirow[t]{2}{*}{ B-40 } \\
\hline & 1.0571 & 0.9030 & & 0.9727 & 0.8577 & 0.8782 & \\
\hline RI-604 & RI-600 & RI-610 & Rl-579 & RI-569 & RI-611 & RI-574 & RI-608 \\
\hline 1.1164 & 1.1618 & 1.1838 & 1.1200 & 0.9521 & 1.1971 & 0.9211 & 1.0529 \\
\hline RI-596 & RI-584 & RI-594 & AL-6 & AL-3 & RI-578 & AL-8 & Rl-598 \\
\hline 1.0536 & 1.0358 & 1.1887 & & & 1.1268 & & 1.0426 \\
\hline RI-581 & AL-2 & RI-567 & AL-5 & AL-7 & Rl-592 & RI-585 & RI-588 \\
\hline 0.9962 & & 1.0373 & & & 1.1752 & 1.0878 & 0.8964 \\
\hline RI-603 & Rl-572 & RI-612 & Rl-571 & Rl-580 & Rl-591 & Rl-597 & RI-607 \\
\hline 1.0278 & 0.9179 & 1.2252 & 1.0035 & 1.0940 & 1.1106 & 1.0924 & 1.0872 \\
\hline$B S+54$ & RI-577 & RI-566 & Rl-564 & AL-1 & RI-568 & RI-590 & B-06 \\
\hline NS & 0.8524 & 0.8110 & 0.9033 & & 0.9025 & 0.9875 & \\
\hline B-10 & Rl-606 & RI-573 & RI-593 & RI-582 & RI-595 & RI-601 & B-03 \\
\hline & 0.9495 & 0.7464 & 0.9551 & 0.9676 & 0.9425 & 0.9642 & \\
\hline
\end{tabular}

$\mathrm{B}=$ Beryllium, BS $+=$ Beryllium Stopper with plug,

$\mathrm{Al}=$ Aluminum Stopper without plug,

$\mathrm{RI}=$ Fuel Element, NS = Neutron Source

Figure 6. RSG-GAS Core Configuration Number 95 with PPF Values
However, the operator team must be well-informed with the physical models, their accuracy and limitations before using their results in real practice. The power distribution in RSG-GAS research reactor depends on several conditions, namely fuel type and enrichment, loading pattern, in-core water gaps, axial and radial influence of (partly) inserted control rods, and burn-up. RSG-GAS research reactor core is normally small compare to NPP, of regular shape and heterogeneous. Power density distribution is peaked, tilted and complicated. Note that the maximum power density occurs near water gaps (empty positions) due to the increase of thermal flux. It is important to note that the power density depends also on the volume of the core. In RSG-GAS research reactor, it is normal that the effective volume of the core is unchanged because the number of fuel elements in the reactor is fixed. Equilibrium operation core contains more than 48 fuel elements. RSG-GAS research reactor cores are always reflected (water and beryllium) and their peak-to-average radial and axial power density values are reduced typically to 1.7 and 1.4 , respectively; these are the values normally assumed in thermal-hydraulics analysis in RSG-GAS reactor. Radial heterogeneity may, however, significantly increase local radial power peaking values (the axial power peaking factor is not so sensitive because the axial structure of the reactor is normally not changed).

\section{RSG-GAS Reactor Operation}

The operation data for RSG-GAS reactor until core 95 has been already collected. RSG-GAS reactor has been operated since 1987 with no serious accident. The total nuclear energy which has been generated from the RSG-GAS reactor is 59,129.9 MWD with total operation 96,056.6 hours to serve the users. The reactor has been utilized to produce radioisotope, 
neutron beam experiments, irradiation of fuel element and its structural material, and reactor physics experiments. At first, the reactor was operated around 750 MWD per cycle, but now RSG-GAS reactor is operated around 660 MWD per cycle. Since 1995, the RSG-GAS reactor has been operated around 4000-5000 hours/year. This reactor operation program is still being maintained within the next few years from now on. Data on the RSG-GAS reactor operation since 1987 is depicted in Figure 7. Up to the beginning of 1997, operation mode of this reactor was fixed to 5 day continuous operation at 22-25 MW and followed with 2 day shut-down; it lasted until the reactor core needed to be resuffled. In one year, 5-6 core resuffling has been scheduled. During resuffling of the reactor core, maintenance activities of the reactor systems were performed. Since fiscal year 1997/1998, operation mode of this reactor was changed became 12 day continuous operation at $15 \mathrm{MW}$ and then followed with 9 day shut-down period. In one year, only 4-core reshuffling was planned. Using this operation mode, around 4000 hour reactor operation per year would be achieved.

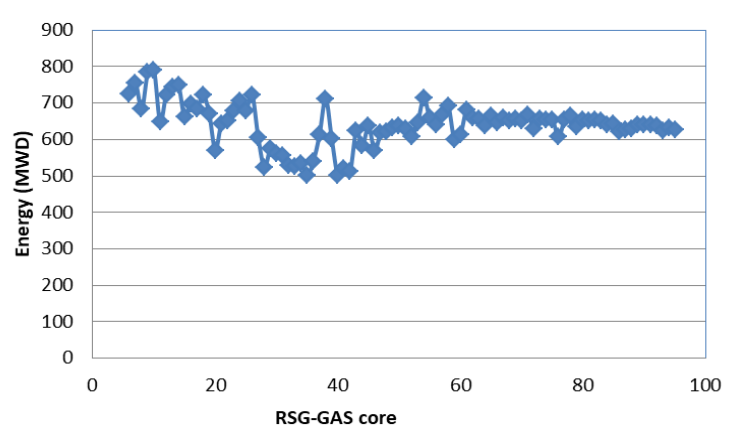

Figure 7. Operation of Each Cycle at RSG-GAS Reactor

\section{Shut-Down Margin}

The shut-down margin is defined as negative reactivity by which the reactor is subcritical if all control rods were inserted in the core except the most reactive one. By this requirement, it is provided that the
RSG-GAS reactor can be made subcritical even if one of the control rods fails (the one with the highest worth). Typical shut-down margin value for stuck rod condition for RSG-GAS research reactors is $-0.5 \$$ $\left(1 \$=1 \beta_{\text {eff }}=0.00765\right)$. It can show shut-down margin reactivity for a stuck rod condition in Figure 8. Safety limits state that if there is a stuck rod condition, reactivity is required for shut-down margin of $-0.5 \%$. This means that all working core is fulfilled so it can operate the reactor because the reactor can still be shut down even though one control rod does not move into the core.

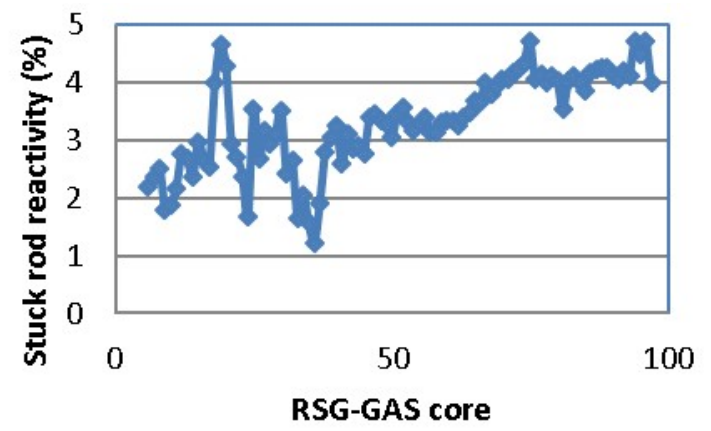

Figure 8. Stuck Rod Reactivity for RSG-GAS Core

It shows the shutdown reactivity in Figure 9, varies from $-2.63 \%$ at $\mathrm{T}-36$ to $-7.14 \%$ at $\mathrm{T}-19$. The size of this shut-down reactivity depends on the ability to absorb the absorber elements inside the control rod of the core. It is expected to be distributed and almost the same as the 8 control rods on the core. it determines the measurement data based on the reactivity determination at the critical position of the reactor without the influence of the neutron source at the Beginning of the Operating Cycle (BOC). For high power operating conditions, reactor shut-down reactivity will increase due to the addition of xenon reactivity, and this shut-down reactivity will increase as the reactor operation increases. If the reactor is scrammed during high power operation, xenon generation will occur. If this happens at the beginning of the cycle, then in less than two hours, the reactor can still be in 
critical condition back to its original power, but if the reactor is scrammed in the middle or end of the cycle, then it is less likely to make the reactor critical in a short time, because the xenon concentration in the core is increasing. In this condition, the reactivity goes out to reach the maximum value, which is equal to the total reactivity of the control rod. It takes time for the xenon concentration to decay so that the reactor can be re-critical; it calls which reactor dead time. Shut-down margin is determined experimentally by measuring the excess reactivity and the worth of all control rods at zero power xenon free conditions. It is done to measure it every time when the core configuration is changed as the control rod worth and excess reactivity both depend on the number and type of fuel selements in the core, their burn-up and loading pattern. Figure 9, shows the shutdown margin for the RSG-GAS working core. The RSG-GAS working core from core configuration number 6 until 95 the shutdown margin were higher than $2 \%$. It means it fulfiled the safety margin of $2 \%$.

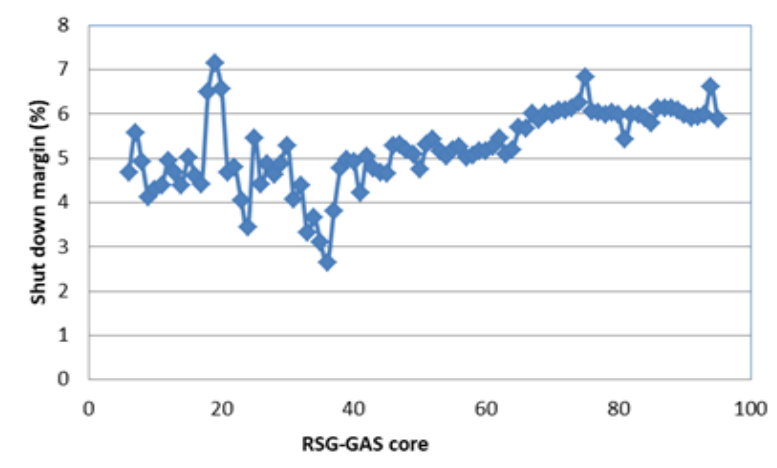

Figure 9. Shut-Down Margin for RSG-GAS Core

\section{Temperature Reactivity Coefficients}

It defines temperature reactivity coefficient reactivity changes per unit temperature change. Three temperature coefficients are defined regarding which temperature change is considered, e.g. fuel temperature reactivity coefficient, coolant temperature reactivity coefficient (sometimes denoted moderator temperature reactivity coefficient also in RSG-GAS reactors where the principal moderator is included in the fuel material), and isothermal reactivity coefficient. It defines the fuel temperature coefficient as reactivity change per unit fuel temperature change at fixed coolant temperature. It defines coolant temperature coefficient is defined as reactivity change per unit coolant temperature change at a fixed fuel temperature. It defines the isothermal coefficient as reactivity change per unit change of fuel and coolant temperature. If a moderator differs from the coolant, the moderator reactivity coefficient can be defined. Fuel temperature reactivity coefficient is important for reactivity and power excursion transient analysis where power feedback effects depend on the sign, rate and time delay of fuel temperature reactivity effects. Negative and by prompt fuel temperature reactivity coefficient is one of the basic safety requirements in RSG-GAS research reactors.

The main contribution to the coolant temperature coefficient is water density temperature variation. The water density can be related to the void reactivity coefficient. It is negative in under moderated and positive in over moderated reactors. It is important in reactivity analysis of coolant flow and temperature. The isothermal coefficient is important because it is the only one that can be calculated. Calculating the temperature coefficients is workable only for special or hypothetical conditions. In the calculations, it is easy to change fuel temperature without changing coolant temperature, however, this is very difficult to carry out in a practical experiment. Fuel temperature at power does not change fuel elements. In the calculation and in the measurement it is necessary to consider the radial and axial temperature distribution. The core management codes are not appropriate for temperature reactivity 
Jurnal Penelitian Fisika dan Aplikasinya (JPFA), 2019; 9(1): 78-91

coefficient calculations without modifications. However, experience shows that good estimates of the coefficients can be got in a unit cell approximation provided that the core is uniform. The coefficients are not a simple mixture of the unit-cell coefficients of the constituents. The contributions of different fuel elements depend on their neutron importance, requiring at least two-dimensional full-core models for reliable estimates. It relates to fuel temperature and power. Power coefficient (defined as reactivity change per unit reactor power) and power defect (integral of power coefficient from zero power to a certain power) are measured. Core management codes are designed to reproduce the power defect by self-adjusting temperature and power distributions using an empirical correlation between fuel element power and temperature.

The effect of temperature or power self-adjusting at the RSG-GAS research reactors is not as strong as in big power reactors where power distributions are "soft" and sensitive to small perturbations. The phenomenon of changes in the value of reactivity that is negative is caused by 3 things:

1. The Doppler effect, where the resonant neutron energy spectrum is absorbed by the fertile ${ }^{238} \mathrm{U}$ fuel with a large absorption cross-section.

2. Thermal expansion in ${ }^{235} U$ fuels so that the density decreases, this affects the probability of thermal neutron capture which results in fission reactions.

3. Shifting the neutron energy spectrum due to increase of thermal energy on the core. The heat energy produced by the fission reaction will cause the thermal neutron spectrum to shift to the neutron resonance spectrum or even the fast neutron spectrum so that the probability of absorption in the ${ }^{235} \mathrm{U}$ decreases.

Table 1. Reactivity Coefficient of RSG-GAS Core

\begin{tabular}{lccc}
\hline \multirow{2}{*}{ Reactivity coeffiecients } & \multicolumn{2}{c}{ Uranium silicide density of $2.96 \mathrm{gU} / \mathrm{cm}^{3}$} \\
& ENDF.BIV & ENDF.B.VII.0 & Design \\
\hline Fuel temperature reactivity coefficient & $-1.62 \times 10^{-3}$ & $-1.65 \times 10^{-3}$ & $-1.60 \times 10^{-3}$ \\
{$\left[\% \Delta k / k /{ }^{\circ} \mathrm{C}\right]$} & & - & \\
Moderator temperature reactivity coefficient & $-6.51 \times 10^{-3}$ & $-7.70 \times 10^{-3}$ & $-6.40 \times 10^{-3}$ \\
{$\left[\% \Delta k / k /{ }^{\circ} \mathrm{C}\right]$} & & $-7.09 \times 10^{-3} \mathrm{E}$ & - \\
Moderator density: & & & $-1.41 \times 10^{-2}$ \\
In unit $\left[\% \Delta k / k / \mathrm{m}^{-3} \mathrm{~kg}\right]$ & $-1.32 \times 10^{-2}$ & $-6.52 \times 10^{-3}$ & $-5.70 \times 10^{-3}$ \\
In unit $\left[\% \Delta k / k /{ }^{\circ} \mathrm{C}\right]$ & $-6.77 \times 10^{-3}$ & $-1.34 \times 10^{-1}$ & $-1.20 \times 10^{-1}$ \\
Void $(\% \Delta k / k / \%$ void) & $-1.38 \times 10^{-1}$ & & \\
\hline
\end{tabular}

Table 2. Reactivity Coefficients of Several Cores

\begin{tabular}{lccc}
\hline Reactivity coeffiecients & Reactors \\
& TRR [24] & MNSR [25] & VRR-2 [26] \\
\hline $\begin{array}{l}\text { Fuel temperature reactivity coefficient } \\
{\left[\% \Delta k / k /{ }^{\circ} \mathrm{C}\right]}\end{array}$ & $-1.39 \times 10^{-3}$ & $-0.63 \times 10^{-3}$ & $-1.01 \times 10^{-3}$ \\
Moderator temperature reactivity coefficient & $-13.65 \times 10^{-3}$ & $-1.43 \times 10^{-3}$ & $-7.31 \times 10^{-3}$ \\
{$\left[\% \Delta k / k /{ }^{\circ} \mathrm{C}\right]$} & & & $-3.41 \times 10^{-1}$ \\
Void $(\% \Delta k / k / \%$ void $)$ & - & - & - \\
\hline
\end{tabular}


Jurnal Penelitian Fisika dan Aplikasinya (JPFA), 2019; 9(1): 78-91

Those are factors that cause reduce of fuel reactivity. The Doppler effect is the factor that contributes significantly to the negative fuel temperature reactivity coefficient. In the charge of 250 gram silicide fuel, similar data is produced, namely the value of the reactivity change and the negative value of the fuel and moderator temperature reactivity coefficients. The results can be seen Table 1 .

Several results from other reactors can be seen in Table 2. All coeffiecient of reactivity are negative for other reactor cores. It means that characteristic of the core is undermoderated, the reactors have good safety parameters. Coefficient reactivity is of fuel always bigger than coefficient reactivity of moderator. It was also achieved at RSG-GAS reactor core.

\section{IV.CONCLUSION}

It discusses general aspects of neutronic safety-related parameters calculations of research reactor. The specific aspects depend on the reactor and fuel type, operating conditions, and software available for reactor calculations. The computer codes and the calculation procedures must be well-understood and verified before being applied to a practical core safety analysis in a particular situation. According to the results of the experimental data and calculation, neutronic safety parameters have met safety analysis report and nothing has violated the safety margin.

\section{ACKNOWLEDGMENT}

We would like to thank the Head of PRSG and PTKRN Batan for the opportunity to conduct this research. Similarly to Head of BFTR and other research associates for their input and suggestions to make this study much better and can evaluate the safety of the RSG-GAS reactor operation.

\section{REFERENCES}

[1] Setiyanto and Surbakti T. Analysis of Gamma Heating at TRIGA Mark Reactor Core Bandung Using Plate-type Fuel. Jurnal Tri Dasa Mega. 2016; 18(3): 127-134. DOI:

http://dx.doi.org/10.17146/tdm.2016.1.3.30 04.

[2] Rahgoshaya $M$ and Kalkhoran ON. Calculation of Control Rod Worth and Temperature Reactivity Coefficient of Fuel and Coolant with Burn-up Changes for VVRS-2 MWth Nuclear Reactor. Journal of Nuclear Engineering and Design. 2013; 256: 322-331. DOI:

https://doi.org/10.1016/j.nucengdes.2012.0 8.033.

[3] Surbakti $\mathrm{T}$ and Tagor MS. Neutronics Analysis on Mini Test Fuel in the RSG-GAS Core. Jurnal Tri Dasa Mega. 2016; 18(1): 29-40. DOI:

https://doi.org/10.17146/tdm.2016.18.1.23 $\underline{29}$.

[4] Surbakti T and Imron M. Fuel Burn-up Calculation for RSG-GAS Working Core. Jurnal Penelitian Fisika dan Aplikasinya (JPFA). 2017; 7(2): 89-101. DOI: 10.26740/jpfa.v7n2.p89-101.

[5] Rokhmadi and Surbakti T. Effect of Fuel Density on Reactivity Coefficient Parameter of the RRI Core Design. Jurnal Tri Dasa Mega. 2013; 15(2): 77-89. Available from:

http://jurnal.batan.go.id/index.php/tridam/a rticle/view/1865.

[6] Suparlina L. RSG-GAS Core Conversion Management of High Loaded Silicide Fuels. Jurnal Tri Dasa Mega. 2013; 15(3): 137-149. Available from:

http://jurnal.batan.go.id/index.php/tridam/a rticle/view/1860.

[7] Surbakti $\mathrm{T}$ and Purwadi, Reactivity Characteristic of the RSG-GAS Working Core for 30 Years Operation. Jurnal Penelitian Fisika dan Aplikasinya (JPFA). 
Jurnal Penelitian Fisika dan Aplikasinya (JPFA), 2019; 9(1): 78-91

2017; $7(1): \quad$ 13-26. DOI: https://doi.org/10.26740/jpfa.v7n1.p13-26.

[8] Surbakti T, Surian P, Tagor MS, Lily S, and Jati S. Neutronics Conceptual Design of the Innovative Research Reactor Core Using Uranium Molybdenum Fuel. Jurnal Tri Dasa Mega. 2012; 3(14): 178-191. Available from:

http://jurnal.batan.go.id/index.php/tridam/a rticle/view/1878.

[9] Surbakti T, Tagor MS, and Surian P. Analysis of Silicide Fuel Density Effect on the Kinetic Parameters of the RSG-GAS Reactor Core. Jurnal Penelitian Fisika dan Aplikasinya (JPFA). 2013; 3(1): 19-30. DOI:

https://doi.org/10.26740/jpfa.v3n1.p19-30.

[10] Iman K and Tagor MS. Alternative Core Design for Innovative Research Reactor (RRI) from the Neutronic Aspect. Jurnal Tri Dasa Mega. 2014; 16(1): 1-10.

Available from:

http://jurnal.batan.go.id/index.php/tridam/a rticle/view/1854.

[11] Batan. Safety Analysis Report of RSG-GAS rev 10.1. Batan; 2011.

[12] Hong LP. Development of an In-core Fuel Management Code for Serching Equilibrium Core in 2-D Reactor Geometry (BATAN-EQUIL-2D). Atom Indonesia. 1997; 23(1): 1-19. Available from: https://www.researchgate.net/publication/2 63593424_Development_of_An_In-Core Fuel_Management_Code for_Searching Core Equilibrium_Condition_in 2-D_Rea ctor_Geometry_Batan-EQUIL-2D.

[13] Pinem S, Sembiring TM, and Leim PH. Neutronic and Thermal-Hydraulic Safety Analysis for the Optimization the Uranium Target in the RSG-GAS Reactor. Atom Indonesia. 2016; 42(3): 123-128. DOI: https://doi.org/10.17146/aij.2016.532.

[14] Hussien HM, Amin EH, and Sakr AM. Effect of Core Configuration on the Burn up Calculations of MTR Research
Reactors. Annals of Nuclear Energy. 2014; 63: 285-294. DOI:

https://doi.org/10.1016/j.anucene.2013.06. $\underline{029}$.

[15] Surbakti T, Pinem S, and Suparlina L. Dynamic Analysis on the Safety Criteria of the Conceptual Core Design in MTR-type Research Reactor. Journal Atom Indonesia. 2018; 44(2): 89-98. DOI: https://doi.org/10.17146/aij.2018.545.

[16] Liem PH, Surbakti T, and Donny S. Kinetics Parameters Evaluation on the First Core of the RSG GAS (MPR-30) Using Continuous Energy Monte Carlo Method. Progress in Nuclear Energy. 2018; 109: 196-203. DOI:

https://doi.org/10.1016/j.pnucene.2018.08. $\underline{014}$.

[17] Pinem S, Liem PH, Tagor MS and Surbakti T. Fuel Element Burn up Measurements for the Equilibrium LEU Silicide RSG GAS (MPR-30) Core under a New Fuel Management Strategy. Annals of Nuclear Energy. 2016; 98: 211-217. DOI: http://dx.doi.org/10.1016/j.anucene.2016.0 $\underline{8}$.

[18] Pinem S, Tagor MS, Surbakti T, and Sunaryo GR. Reactivity Coefficient Calculation for AP1000 Reactor Using the NODAL3 Code. Journal of Physics: Conference Series. 2018; 962(1): 012057. DOI:

https://doi.org/10.1088/1742-6596/962/1/0 12057.

[19] Pinem S, Sembiring MS, Surbakti T, and Kuntoro I. Neutronic Analysis on Irradiation of the Leu Electroplating Target in the RSG-GAS Reactor for Production of 99mo Radionuclide. GANENDRA Majalah IPTEK Nuklir. 2018; 21(2): 55-61. DOI: https://doi.org/10.17146/gnd.2018.21.2.43 9.

[20] Pinem S, Surbakti T, and Tagor MS. Core Design TRIGA2000 Bandung using U3Si2Al Fuel Element MTR Type. Urania 
Jurnal Penelitian Fisika dan Aplikasinya (JPFA), 2019; 9(1): 78-91

Jurnal Ilmiah Daur Bahan Bakar Nuklir. 2018; 24(2): 93-103. DOI:

https://doi.org/10.17146/urania.2018.24.2. 4302.

[21] Hastuti EP, Surbakti T, Widodo S, and Sudarmono. Abnormal Control Rod withdrawal Analysis for Innovative Research Reactor using PARET-ANL codes. Kerntechnik. 2018; 83(2): 96-105. DOI: https://doi.org/10.3139/124.110844.

[22] Pinem S, Sembiring TM, and Surbakti T. Core Conversion Design Study of TRIGA Mark 2000 Bandung using MTR Plate Type Fuel Element. International Journal of Nuclear Energy Science and Technology. 2018; 12(3): 222-238. DOI: https://doi.org/10.1504/IJNEST.2018.0956 $\underline{89}$.

[23] Dibyo S, Sudjatmi KS, Sihana, and Irianto ID. Simulation of Modified TRIGA-2000 with PlateType Fuel under LOFA using EUREKA2/RR-Code. Atom Indonesia. 2018; 44(1): 31-36. DOI: https://doi.org/10.17146/aij.2018.541.
[24] Torabi M, Lashkari A, Masoudi SF, and Bagheri S. Neutronic Analysis of Control Rod Effect on Safety Parameters in Tehran Research Reactor. Nuclear Engineering and Technology. 2018; 50(7): 1017-1023. DOI:

https://doi.org/10.1016/j.net.2018.05.008.

[25] Alhassan E, Akaho EHK, Nyarko BJB, Adoo NA, Agbodemegbe VY, Bansah CY, and Della R. Analysis of Reactivity Temperature Coefficient for Light Water Moderated HEU-UAL 4 and LEU-UO ${ }_{2}$ Lattices of MNSR. Journal of Applied Sciences Research. 2010; 6(9): 1431-1439. Available from:

https://researchgate.net/publication/255685 7421.

[26] Rahgoshaya $M$ and O. Noori-Kalkhoran. Calculation of Control Rod Worth and Temperature Reactivity Coefficient of Fuel and Coolant with Burn-up Changes for VVRS-2 MWth Nuclear Reactor. Nuclear Engineering and Design. 2013; 256: 322-331. DOI:

http://dx.doi.org/10.1016/j.nucengdes.2012 .08 .033 . 